Abstracta Iranica Abstracta Iranica

Revue bibliographique pour le domaine irano-aryen

Volume 26 | 2005

Comptes rendus des publications de 2003

\title{
«Les inscriptions hatréennes : un bilan ». Topoi 10,1 (2000) [2002], Dossier Hatra, pp. 217-227, 7 figs.
}

\section{Karin Mosig-Walburg}

\section{(2) OpenEdition \\ 12 Journals}

\section{Édition électronique}

URL : http://journals.openedition.org/abstractairanica/3440

ISSN : 1961-960X

Éditeur :

CNRS (UMR 7528 Mondes iraniens et indiens), Éditions de l'IFRI

Édition imprimée

Date de publication : 15 mai 2005

ISSN : 0240-8910

Référence électronique

Karin Mosig-Walburg, « «Les inscriptions hatréennes : un bilan ». Topoi 10,1 (2000) [2002], Dossier

Hatra, pp. 217-227, 7 figs. », Abstracta Iranica [En ligne], Volume 26 | 2005, document 145, mis en ligne le 08 décembre 2005, consulté le 25 septembre 2020. URL : http://journals.openedition.org/

abstractairanica/3440

Ce document a été généré automatiquement le 25 septembre 2020.

Tous droits réservés 


\section{"Les inscriptions hatréennes : un bilan ». Topoi 10,1 (2000) [2002], Dossier Hatra, pp. 217-227, 7 figs.}

Karin Mosig-Walburg

1 Court aperçu de différents aspects des inscriptions hatréennes (plus de 400) : langue, écriture, caractère et chronologie.

INDEX

Thèmes : 3.2.3. Séleucides, Parthes et Sassanides

\section{AUTEURS}

KARIN MOSIG-WALBURG

Université de Francfort 